\title{
PENGGUNAAN METODE SOSIODRAMA MELALUI LAYANAN BIMBINGAN KELOMPOK UNTUK MENINGKATKAN KEMAMPUAN INTERPERSONAL SISWA KELAS X TKR A SMK N 2 SALATIGA TAHUN PELAJARAN 2018/2019
}

\author{
Rohman Afandi ${ }^{1}$, Tritjahjo Danny Soesilo ${ }^{2}$, Yustinus Windrawanto ${ }^{3}$ \\ Email:132015020@student.uksw.edu ${ }^{1}$,tritjahjo.danny@uksw.edu ${ }^{2}$, \\ windrawanto@staff.uksw.edu ${ }^{3}$ \\ Program Studi Bimbingan dan Konseling FKIP Universitas Kristen Satya Wacana ${ }^{1,2,3}$
}

\begin{abstract}
Abstrak
Penelitian ini bertujuan untuk mengetahui peningkatan kemampuan interpersonal dengan metode sosiodrama melalui layanan bimbingan kelompok pada siswa kelas X TKR A SMK N 2 Salatiga Tahun Pelajaran 2018/2019. Jenis penelitian ini adalah penelitian tindakan bimbingan konseling. Subjek penelitian siswa kelas X TKR A SMK N 2 Salatiga yang mempunyai kemampuan interpersonal kategori rendah yaitu berjumlah 5 siswa. Penelitian ini dilakukan dengan berkolaborasi dengan guru bimbingan dan konseling sebagai observer. Metode sosiodrama dilakukan dalam 1 siklus 2 tindakan dalam 4 pertemuan. Metode pengumpulan data yang digunakan adalah instrumen penelitian dengan skala kemampuan interpersonal, dan pedoman observasi. Analisis data menggunakan analisis deskriptif komparatif. Dengan indikator keberhasilan, $\geq 80 \%$ dari subjek penelitian memiliki kemampuan interpersonal tinggi. Hasil penelitian ini yaitu: (1) Kondisi awal dari hasil pre-test menunjukan 5 siswa mempunyai kemampuan interpersonal agak rendah, dengan skor rata-rata kemampuan interpersonal 144,2. (2) Siklus 1 diberikan tindakan sosiodrama yang meliputi 2 tindakan bermain drama dengan tema: Persahabatan dan Berorganisasi. Setelah diberikan tindakan sosiodrama, kemampuan interpersonal siswa mengalami peningkatan. Dari hasil pos-test yang menunjukan skor rata-rata kemampuan interpersonal sebesar 186,6, dan dikategorikan kemampuan interpersonal tinggi. Penelitian ini dinyatakan berhasil karena $80 \%$ dari subjek (4 siswa) sudah meningkat kekategori kemampuan interpersonal tinggi. Berdasarkan observasi, setelah diberikan layanan sosiodrama dari tindakan I dan II siswa menunjukan antusias tinggi dan perubahan sikap yang mangacu pada kemampuan interpersonal tinggi.
\end{abstract}

Kata Kunci: Kemampuan Interpersonal; Bimbingan Kelompok; Metode Sosiodrama

\begin{abstract}
This study aims to determine the improvement of interpersonal skills with the sociodrama method through group guidance services in class X TKR A SMK N 2 Salatiga Academic Year 2018/2019. This type of research is counseling action research. The research subjects of class $X$ TKR A SMK $N 2$ Salatiga had low category interpersonal skills, amounting to 5 students. This research was conducted in collaboration with the guidance and counseling teacher as an observer. The sociodrama method was carried out in 1 cycle of 2 actions in 4 meetings. The data collection method used is a research instrument with interpersonal ability scale, and observation guidelines. Data analysis using descriptive comparative analysis. With indicators of success, $\geq 80 \%$ of research subjects have high interpersonal skills. The results of this study are: (1) The initial condition of the pre-test results showed 5 students had rather low interpersonal abilities, with an average score of interpersonal abilities 144.2. (2) 1st Cycle is given sociodrama action which includes 2 actions to play drama with the theme: Friendship and Organizing. After being given sociodrama action, students' interpersonal skills improved. From the results of the post-test which showed an average score of interpersonal skills of 186.6, and categorized as high interpersonal skills. This study was declared successful because $80 \%$ of subjects (4 students) had increased categories of high interpersonal skills. Based on observations, after being given sociodrama services from the 1st and 2nd actions, students showed high enthusiasm and attitude changes that led to high interpersonal skills.
\end{abstract}

Keywords: Interpersonal Ability, Group Giudance; Sosiodrama Method 


\section{PENDAHULUAN}

Masa remaja adalah masa dimana rasa keingintahuan anak bergejolak ingin dipenuhi. Di masa ini disebut juga sebagai masa pencarian jatidiri untuk prinsip hidup di tahap perkembangan yang lebih matang. Oleh karena itu tidak jarang ditemukan kasus-kasus konflik antar pribadi remaja dalam kehidupan sehari-harinya. Konflik tersebut bisa terjadi karena beda pendapat antar individunya, atau perbedaan cara pandang mereka tentang suatu permasalahan. Tidak hanya di lingkungan keluarga layaknya adik dan kakak, atau antar teman sebaya di lingkungan bermainnya, tapi juga antar pribadi remaja di lingkungan sekolah.

Dalam pergaulan remaja atau siswa di sekolah, guru bimbingan dan konseling yang bertanggungjawab secara langsung untuk membimbing dan mengarahkan siswa dituntut untuk kreatif dan efektif dalam memberikan pelayanannya. Berdasarkan pengamatan secara langsung di lapangan ketika praktikum tugas mata kuliah di SMK N 2 Salatiga, ditemukan banyak siswa kelas X TKR A yang masih canggung berbicara dengan temannya sendiri, siswa masih kesulitan dalam bergaul. Beberapa siswa bahkan kurang peduli dengan kondisi teman sekelasnya yang kurang aktif. Siswa yang aktif cenderung mendominasi kondisi kelas dan yang kurang aktif semakin tenggelam. Dengan realita seperti ini bisa dikatakan bahwa siswa kelas X TKR A SMK Negeri 2 Salatiga ini masih memiliki tingkat kemampuan interpersonal yang rendah, siswa cenderung tidak peka terhadap lingkungan di sekitarnya, tidak peduli, egois, dan menyinggung perasaan orang lain. Siswa yang kesulitan dalam membangun kemampuan interpersonal dengan temannya, menyebabkan pola komunikasi yang tidak efektif.

Tabel 1 Data Kemampuan Interpersonal Siswa Kelas X TKR A SMK N 2 Salatiga Dari Pra Penelitian

\begin{tabular}{lcc}
\hline \multicolumn{1}{c}{ Keterangan } & Frekuensi & Jumlah \\
\hline ST (Sangat & $209-238$ & 2 \\
Tinggi) & & \\
T (Tinggi) & $179-208$ & 15 \\
AT(Agak & $149-178$ & 14 \\
Tinggi) & & \\
AR (Agak & $119-148$ & 5 \\
Rendah) & & \\
R (Rendah) & $89-118$ & - \\
SR (Sangat & $59-88$ & - \\
Rendah) & & \\
\multicolumn{2}{c}{ Total } &
\end{tabular}

Kemampuan interpersonal sendiri menurut Burhmester (dalam Qathrin 2008) adalah kemampuan yang dimiliki seseorang untuk memahami berbagai situasi sosial di manapun individu berada serta bagaimana individu tersebut 
menampilkan tingkah laku yang sesuai harapan orang lain yang merupakan interaksi antara individu lainnya. Dengan kemampuan interpersonal yang baik dapat membuat anak mampu untuk berhubungan dengan orang lain secara bermakna dan bermanfaat. Sebaliknya, anak yang memiliki kemampuan interpersonal yang rendah dapat memunculkan konflik interpersonal.

Untuk mencegah agar konflik tidak terjadi, perlu diadakan usaha mengembangkan dan meningkatkan kemampuan interpersonal siswa. Salah satu usaha yang dapat dilakukan oleh guru bimbingan dan konseling dalam membantu siswanya ialah menggunakan metode layanan yang tepat dalam praktiknya, salah satunya metode sosiodrama. Dalam penelitian yang dilakukan oleh Zuhara (2014) metode sosiodrama terbukti efektif untuk meningkatkan kualitas interpersonal siswa. Hal ini juga diperkuat dengan penelitian dari Lubis (2017) yang mengatakan sosiodrama menjadikan siswa lebih selektif dalam meningkatkan komunikasi interpersonal ketika menghadapi suatu masalah. Metode sosiodrama ini dianggap cocok karena disesuaikan dengan masalah siswa yang berkaitan dengan kemampuan antar pribadi masing-masing dalam bersosial.

Roestiyah (dalam Siregar 2014) mengemukakan bahwa dengan menggunakan metode sosiodrama siswa dapat mendramatisasikan tingkah laku, atau ungkapan gerak-gerik wajah seseorang dalam sosial antar manusia, atau siswa dapat memainkan peranan dalam dramatisasi masalah sosial atau psikologis. Metode ini pernah dipakai oleh Siregar (2014) dalam penelitian yang berjudul "Penerapan Metode Sosiodrama untuk Meningkatkan Kemampuan Interpersonal Siswa Kelas VII SMP Negeri 5 Depok Sleman Yogyakarta”. Hasil penelitian ini menunjukan bahwa penerapan sosiodrama yang difokuskan untuk meningkatkan kemampuan interpersonal siswa kelas VII A SMP Negeri 5 Depok Sleman Yogyakarta telah meningkat dari sebelumnya.

Dengan teknik sosiodrama ini nanti siswa kelas X TKR A SMK N 2 Salatiga akan dibimbing untuk memainkan suatu peran permasalahan sosial yang dialami di lingkungannya. Dalam kasus ini berarti di sekolah tempat siswa/subjek belajar. Dengan harapan nanti siswa/subjek bisa saling mengevaluasi, mengetahui dampak yang terjadi bila masalah sosial dilakukan 
dan paham jika perilaku tersebut tidak baik diterapkan dalam kehidupan seharihari mereka.

\section{KAJIAN PUSTAKA}

\section{Kemampuan Interpersonal}

Menurut Johnson (dalam Dyan 2014) kemampuan interpersonal merupakan keseluruhan kemampuan seseorang yang digunakan untuk berinteraksi atau berhubungan secara efektif dengan orang lain. Kapanpun seseorang berinteraksi dengan orang lain, apakah dengan teman, anggota keluarga, kenalan, asosiasi bisnis, maupun yang lainnya. Sedangkan menurut Yaumi (dalam Dyan 2014) kemampuan interpersonal adalah kemampuan yang dibutuhkan untuk berinteraksi dalam situasi sosial. Bagaimana diri kita mampu membangun hubungan yang harmonis dengan memahami dan merespon manusia atau orang lain merupakan bagian dari keterampilan interpersonal.

Dalam pengertian ini, Johnson (dalam Dyan 2014) juga menambahkan adanya aspek-aspek tertentu yang membentuk kemampuan interpersonal. Aspek-aspek tersebut diantaranya yaitu, keterbukaan diri (self disclosure), empati (empathy), kepemimpinan dan kerjasama (leadership and teamwork), membina hubungan dan menjaga hubungan (relationship and networking), berkomunikasi dan bernegoisasi (comunication and negotiation), mendengarkan (listening), menyelesaikan konflik (solve conflict).

\section{Bimbingan Kelompok}

Menurut Winkel (2004) bimbingan kelompok merupakan bimbingan yang diberikan kepada sejumlah individu dalam bentuk kelompok dengan memanfaatkan dinamika kelompok untuk membahas topik tertentu yang dipimpin oleh pemimpin kelompok bertujuan menunjang pemahaman, pengembangan, pertimbangan pengambilan keputusan/tindakan individu. Menurut Romlah (2006) bimbingan kelompok adalah proses pemberian bantuan yang diberikan pada individu dalam situasi kelompok. Pada proses ini berarti pendekatan secara berkelompok digunakan untuk memberikan kesempatan masing-masing individu dapat saling berinteraksi satu dengan yang lainnya. Dalam bimbingan kelompok ini ada beberapa teknik atau metode yang bisa digunakan, yaitu diskusi kelompok, homeroom, karyawisata, pemberian informasi atau sering disebut dengan metode ceramah, dan metode permainan peran (role 
playing) yang di dalamnya terdapat psikodrama dan sosiodrama.

Sedangkan menurut Prayitno (2010) bimbingan kelompok adalah suatu kegiatan yang dilakukan oleh sekelompok individu dengan memanfaatkan dinamika kelompok. Individu diberikan kebebasan untuk menyatakan pendapat, memberi saran, dan saling menanggapi. Prayitno (2010) menyebutkan tahap-tahap bimbingan kelompok ada empat yaitu: tahap pembentukan, tahap peralihan (transisi), tahap kegiatan, dan tahap pengakhiran.

1. Tahap pembentukan

Tahap awal atau tahap permulaan sebagai tahap persiapan dalam rangka pembentukan kelompok. Tahap ini merupakan tahap pengenalan, pemberian hubungan baik.

2. Tahap Peralihan (Transisi)

Tahap ini merupakan tahap transisi dari tahap pembentukan ke tahap kegiatan. Pada tahap ini pemimpin kelompok bertugas menanyakan kesiapan para anggota kelompok sebelumnya supaya kegiatan kelompok bisa berjalan dengan baik dan sesuai dengan rancangan yang sudah dibuat.

3. Tahap kegiatan
Tahap in sering disebut juga sebagai kegiatan inti. Pada tahap ini saatnya anggota berpartisipasi aktif dalam kelompok, tercapainya suasana mengembangkan diri anggota kelompok, baik yang menyangkut pengembangan kemampuan berkomunikasi, mengajukan pendapat, menanggapi pendapat dengan terbuka, maupun menyangkut pemecahan masalah yang dikemukakan dalam kelompok.

4. Tahap Pengakhiran

Pada tahap ini pula, perlunya pemberian evaluasi baik secara proses dan hasil. Supaya antara pemimpin kelompok dan anggota kelompok mampu memahami kekurangan dan kelebihan selama proses kegiatan itu berlangsung.

\section{Sosiodrama}

Wina Sanjaya (2006) menyatakan sosiodrama adalah metode pembelajaran bermain peran untuk memecahkan masalah-masalah yang berkaitan dengan fenomena sosial, permasalahan yang menyangkut hubungan antar manusia seperti kenalan remaja, narkoba, gambaran keluarga yang otoriter dan sebagaianya. Sosiodrama digunakan untuk memberikan pemahaman dan 
penghayatan akan masalah-masalah sosial serta mengembangkan kemampuan siswa untuk memecahkannya.

Roestiyah (dalam Siregar 2014) mengemukakan bahwa dengan menggunakan metode sosiodrama seseorang dapat mendramatisasikan tingkah laku, atau ungkapan gerak-gerik wajah dalam hubungan sosial antar manusia, atau seseorang dapat memainkan peranan dalam dramatisasi masalah sosial atau psikologis.

Metode sosiodrama dipandang sebagai salah satu metode yang efektif untuk meningkatkan kemampuan interpersonal anak. Mulyasa (dalam Hamid 2018) mengatakan bahwa dalam teknik sosiodrama ini siswa mempunyai kesempatan untuk menggali potensi belajar yang dimiliki melalui pemeranan tokoh tertentu kaitannya dengan permasalahan sosial. Dengan kata lain sosiodrama adalah metode pembelajaran bermain peran untuk memecahkan masalah-masalah yang menyangkut hubungan antar manusia seperti kenakalan remaja, gambaran keluarga yang otoriter dan sebagaianya. Sosiodrama digunakan untuk memberikan pemahaman dan penghayatan akan masalah-masalah sosial serta mengembangkan kemampuan siswa untuk memecahkannya (Wina Sanjaya, 2006). Melalui metode sosiodrama ini anak akan lebih mengenal dirinya sendiri dan memahami orang lain. Seperti yang dialami siswa kelas $\mathrm{X}$ TKR A SMK N 2 Salatiga dengan kemampuan interpersonalnya yang rendah, dengan penggunaan sosiodrama ini akan membantu siswa untuk memperbaiki diri berkaitan dengan relasinya dengan orang lain atau temantemannya.

\section{METODE PENELITIAN}

Jenis penelitian ini adalah penelitian tindakan bimbingan dan konseling (PTBK), dengan bentuk penelitian kolaboratif. Menurut Soesilo (2014) dalam bentuk kolaboratif ini pelaksanaannya perlu melibatkan beberapa pihak seperti guru BK, kepala sekolah, dan pihak lainnya yang dipercaya dalam membantu proses pelaksanaan kegiatan penelitian. Arikunto (2006) mengatakan model penelitian ini didesain menggunakan empat tahapan dalam satu siklus, yaitu tahap perencanaan, tahap pelaksanaan tindakan, tahap observasi dan tahap refleksi.

Subjek penelitian dalam penelitian ini yaitu siswa kelas X TKR A SMK N 2 Salatiga sejumlah 5 orang yang mempunyai kategori kemampuan 
interpersonal rendah. Dengan teknik sampel yang digunakan adalah purposive sampling (Soesilo 2014) yaitu cara pengambilan sampel yang tidak mementingkan adanya syarat-syarat tertentu, karena yang menjadi subjek penelitian dalam hal ini adalah orang yang memiliki permasalahan konkrit (kemampuan interpersonal rendah).

Teknik pengumpulan data menggunakan teknik metode skala. Skala yang digunakan dalam penelitian ini mengadaptasi dari penelitian Dyan Tikawati (2014), dengan item pernyataan sejumlah 59 item.

Uji validitas mengacu pada teori Arikunto (2012) dengan koefisiensi validitas $<0,21$ yang mengandung arti bahwa item pernyataan tersebut tidak valid atau item pernyataan gugur. Berdasarkan data yang diperoleh pada uji validitas ini, dapat dikatakan bahwa seluruh item pada skala kemampuan interpersonal ini mencapai standart validitas yaitu berkisar dari angka 0,240 $-0,800$ sehingga 59 item dikatakan valid. Uji reliabiltas mengacu pada teori Azwar (2012), semakin tinggi koefisien reliabilitas mendekati 1,0 berarti semakin tinggi reliabilitas.

Teknik analisis data yang digunakan dalam PTBK ini menggunakan teknik analisis deskripsi komparatif. Teknik analisis deskripsi yang dilakukan dengan membandingkan hasil layanan dari suatu siklus dengan kriteria keberhasilan yang sudah ditentukan. Dan indikator keberhasilan dalam penelitian ini adalah, penelitian dikatakan berhasil apabila $\geq 80 \%$ dari subjek penelitian memiliki kemampuan interpersonal tinggi.

\section{HASIL PENELITIAN DAN \\ PEMBAHASAN}

Penelitian ini dilakukan bulan Oktober 2018 sampai dengan Februari 2019. Dengan populasi dan sampel yang dijadikan subjek penelitian adalah siswa kelas X TKR A SMK N 2 Salatiga sejumlah 5 orang yang mempunyai kategori kemampuan interpersonal rendah. Subyek tersebut diperoleh dari pengamatan (observasi) sebelumnya, ditambah dengan hasil dari pre-test.

Tindakan I dilakukan pada hari Jum'at, 1 Februari 2019. Tindakan dimulai pada pukul 07.30-08.30 WIB, bertempat di gazebo samping ruang kelas TKR. Pada tindakan I ini subjek sudah menunjukan ketertarikan terhadap metode yang akan digunakan, yaitu sosiodrama. Ketertarikan subjek tentang metode ini sebenarnya sudah ditunjukan dengan sikap mereka dari awal yang 
begitu memperhatikan dan semangat latihan memerankan pada pertemuan pertama. Setelah itu mereka semangat dan asik memerankan drama tentang 'Persahabatan'. Hasil observasi bersama guru BK setelah pelaksanaan tindakan I ini, siswa/subjek penelitian sudah mengalami perubahan perilaku yang cukup bagus. Siswa/subjek sudah menunjukan perilaku membuka diri kepada sesama temannya, berusaha menghargai orang lain ketika ada yang berbiacara, berempati dengan membantu teman yang sedang mempunyai masalah, dan menunjukan sikap yang bagus ketika berkomunikasi dengan orang lain.

Tindakan II dilakukan pada hari Jum'at, 15 Februari 2019. Tindakan dimulai pada pukul 07.30-08.30 WIB, bertempat di gazebo samping ruang kelas TKR. Pada tindakan II tema drama yang dimainkan adalah 'Berorganisasi'. Subjek menghayati konflik-konflik yang terjadi, ada satu dua diantaranya yang menjadi penengah untuk menjaga hubungan tetap baik, dan pemimpin yang mendinginkan suasana dan mengajak tetap kompak dalam bekerjasama. Dari observasi bersama guru BK setelah tindakan juga menunjukan kelima siswa yang menjadi subjek penelitian sudah penunjukan perubahan perilaku pada aspek-aspek yang diamati. Rata-rata subjek sudah lebih peduli kesesama temannya dilingkungan kelas maupun sekolah. Subjek terlihat lebih mengutamakan kebersamaan daripada individual. Siswa/subjek sudah paham bahwa konflik sebisa mungkin harus dihindari atau kemungkinan terburuk harus segera diselesaikan agar relasi kedepan tidak bermasalah. Subjek memahami cara mengatasi persoalan dengan berkomunikasi dengan baik dengan teman dan orang lain, sehingga dengan demikian kemampuan interpersonal mereka semakin tinggi.

Berikut ini akan disajikan tabel mengenai data skor peningkatan kemampuan interpersonal pre-test - posttest pada siswa kelas X TKR A SMK N 2 Salatiga yang mempunyai kemampuan interpersonal rendah.

\section{Tabel 2 Peningkatan Kemampuan} Interpersonal pada siswa kelas X TKR A SMK N 2 Salatiga yang Berkategori Rendah.

\begin{tabular}{ccccc}
\hline & \multicolumn{2}{c}{ Pre-test } & \multicolumn{2}{c}{ Post-test } \\
\cline { 2 - 5 } Nama & 146 & $\begin{array}{c}\text { Agak } \\
\text { Rendah } \\
\text { Agak } \\
\text { Bendah } \\
\text { Ags }\end{array}$ & 183 & Tinggi \\
FM & 146 & 181 & Tinggi \\
FE & 141 & $\begin{array}{c}\text { Angi } \\
\text { Rendah } \\
\text { Agak } \\
\text { Rendah } \\
\text { Agak }\end{array}$ & 193 & Tinggi \\
NK & 146 & $\begin{array}{c}\text { Thategor } \\
\text { Rendah }\end{array}$ & $\begin{array}{c}\text { Agak } \\
\text { tinggi }\end{array}$ \\
\hline
\end{tabular}

Dari tabel di atas diketahui bahwa hasil dari post-test siswa-siswa kelas $\mathrm{X}$ TKR A yang memliki kemampuan 
interpersonal kategori rendah meningkat menjadi tinggi, hanya satu orang yang menunjukan peningkatan ke kategori agak tinggi. Mengacu pada indikator penelitian ini yang menyatakan berhasil apabila $\geq 80 \%$ dari subjek penelitian memiliki kemampuan interpersonal tinggi, maka penelitian ini dikatakan berhasil karena $80 \%$ dari subjek penelitian (4 siswa) mengalami peningkatan ke dalam kategori tinggi. Hanya 1 siswa yang meningkat ke kategori agak tinggi.

Dari tabel tersebut juga dapat diketahui skor total peningkatan kemampuan interpersonal siswa kelas $\mathrm{X}$ TKR A SMK N 2 Salatiga sebagai berikut:

Tabel 3 Data Skor Total Peningkatan Kemampuan Interpersonal pada Siswa kelas $X$ TKR A SMK N 2 Salatiga yang Berkategori Rendah.

\begin{tabular}{cccc}
\hline $\begin{array}{c}\text { Keteran } \\
\text { gan }\end{array}$ & $\begin{array}{c}\text { Rata-rata } \\
\text { Pre-Test }\end{array}$ & $\begin{array}{c}\text { Rata-rata } \\
\text { Post-Test }\end{array}$ & $\begin{array}{c}\text { Pening } \\
\text { katan }\end{array}$ \\
\hline $\begin{array}{c}\text { Kemam } \\
\text { puan }\end{array}$ & & & \\
$\begin{array}{c}\text { Interper } \\
\text { sonal }\end{array}$ & 144,2 & 186,6 & 42,4 \\
\hline
\end{tabular}

Tabel di atas menunjukan bahwa

skor total kemampuan interpersonal hasil rata-rata pre-test siswa kelas X TKR A SMK N 2 Salatiga yang dijadikan subjek yaitu 144,2 dan masuk kedalam kategori agak rendah. Kemudian skor total kemampuan interpersonal hasil rata-rata post-test menunjukan skor 186,6 dan masuk kedalam kategori tinggi. Data tersebut menunjukan peningkatan dari pre-test ke post-test sebesar 42,4.

Dari tabel tersebut juga memberikan penguatan bahwa metode sosiodrama melalui layanan bimbingan kelompok dapat meningkatkan kemampuan interpersonal siswa kelas $\mathrm{X}$ TKR A SMK N 2 Salatiga yang mempunyai kategori rendah menjadi tinggi.

\section{PENUTUP}

\section{Simpulan}

Berdasarkan hasil analisis data dan pembahasan, maka dapat disimpulkan bahwa metode sosiodrama melalui layanan bimbingan kelompok terbukti meningkatkan kemampuan interpersonal siswa kelas X TKR A SMK N 2 Salatiga yang masih rendah. Hal tersebut dapat dibuktikan dari kondisi awal pre-test, observasi, dan post-test. Dari hasil pretest ditemukan 5 siswa kelas X TKR A SMK N 2 Salatiga yang mempunyai kategori agak rendah, dengan total skor rata-rata 144,2 yang selanjutnya dijadikan subjek penelitian. Selanjutnya, pada siklus I diberikan treatment dengan metode sosiodrama dengan 2 tindakan bermain drama dengan tema tentang: Persahabatan dan Berorganisasi, sehingga kemampuan interpersonal subjek meningkat. Peningkatan tersebut 
dibuktikan dari hasil post-test dengan perolehan total skor rata-rata 186,6 dan dikategorikan kemampuan interpersonal tinggi. Dengan peningkatan total skor rata-rata kemampuan interpersonal dari pre-test ke post-test yaitu 42,4 poin. Mengacu pada indikator keberhasilan penelitian, penelitian ini dikatakan berhasil karena $80 \%$ dari subjek penelitian (4 siswa) mengalami peningkatan ke dalam kategori tinggi. Hanya 1 siswa yang meningkat ke kategori agak tinggi.

\section{Saran}

Berdasarkan kesimpulan hasil penelitian yang telah dipaparkan diatas, maka ada bebrapa saran yang perlu disampaikan sebagai berikut:

Untuk Siswa. Metode sosiodrama melalui layanan bimbingan kelompok terbukti dapat meningkatkan kemampuan interpersonal. Diharapkan siswa-siswa yang lain juga bisa ikut bergabung bermain dalam sosiodrama agar kehidupan bersosialnya terutama di lingkungan kelas dan sekolah terjalin dengan baik dan efektif, saling peduli, empati, dan menumbuhkan sikap saling kerjasama yang positif.

Guru BK. Lebih kreatif dan inovatif lagi dalam pemberian layanan kepada siswa. Contohnya dengan metode sosiodrama, karena siswa lebih antusias dan merasa mendapat hal baru yang tidak monoton dari sekedar bimbingan klasikal dengan tatap muka di kelas. Metode sosiodrama melalui layanan bimbingan kelompok dapat digunakan sebagai salah satu metode bimbingan untuk mengatasi dan membantu siswa yang memiliki masalah dengan kemampuan interpersonal.

Untuk Sekolah. Sekolah diharapkan lebih mendukung kegiatan guru BK dalam memberikan layanan berupa drama kepada siswa. Fasilitas penunjang pelaksanaan layanan lebih dilengkapi agar pelayanan sosiodrama lebih efektif dan nyaman.

Untuk Penelitian Selanjutnya. Diharapkan untuk lebih maksimal bekerjasama dengan guru BK sebagai kolaborator dalam tahapan-tahapan tindakan. Hal tersebut dilakukan supaya guru BK dapat terlibat langsung sehingga saran perbaikan tidak hanya dari peneliti.

\section{DAFTAR PUSTAKA}

Arikunto, Suharsimi. 2006. Penelitian Tindakan Kelas. Jakarta: Bumi Aksara

Arikunto, S. 2012. Prosedur Penelitian Suatu Pendekatan Praktik. Jakarta: PT. Rajagrafindo Persada

Azwar, Saifuddin. 2012. Reliabilitas dan Validitas. Yogyakarta. Pustaka Pelajar 
Hamid, Ilham. 2018. Penerapan Teknik Sosiodrama Dalam Bimbingan Kelompok Untuk Meningkatkan Keterampilan Komunikasi Interpersonal Siswa. Jurnal Mimbar Kesejahteraan Sosial, Edisi 1

Lubis, MR. 2017. Meningkatkan Keterampilan Komunikasi Interpersonal Siswa Melalui Layanan Bimbingan Kelompok Teknik Sosiodrama. Jurnal Diversita Vol. 1, Nomor 2

Nada, Qathrin. 2008. Hubungan Antara Kemampuan Interpersonal Menurut Buhrmester Dengan Iklim Berorganisasi. Skripsi. Jakarta: Fakultas Psikologi Universitas Islam Negeri Syarif Hidayatullah Jakarta.

Prayitno. 2010. Layanan Bimbingan dan Konseling Kelompok. Jakarta: Ghalia Indonesia

Romlah, Tatiek. 2006. Teori dan Praktek Bimbingan Kelompok. Malang: Universitas Negeri Malang.

Sanjaya, Wina. 2006. Strategi Pembelajaran Berorientasi Standar Proses Pendidikan. Jakarta: Prenadamedia Group.

Soesilo, Tritjahjo Danny. 2014. Strategi Pelaksanaan Penelitian Tindakan Dalam Bimbingan \& Konseling. Salatiga: Griya Media

Tikawati, Dyan. 2014. Peningkatan Keterampilan Interpersonal Melalui Permainan. Skripsi. Yogyakarta: Program Studi Bimbingan Dan Konseling Jurusan Psikologi Pendidikan Dan Bimbingan Fakultas Ilmu
Pendidikan Universitas Negeri Yogyakarta.

Winkel, W. S. 2004. Bimbingan dan Konseling di Institusi Pendidikan. Yogyakarta: Media Abadi.

Zuhara, Evi. 2014. Efektivitas Teknik Sosiodrama Untuk Meningkatkan Komunikasi Interpersonal Siswa. Jurnal Ilmiah Edukasi Vol. 1, Nomor 1 